is in some way or other a compound of two other bodies, cerebrine and lecythine; but, oddly enough, we read of "cerebric acid or lecithine ;" and again, the "blood-corpuscles contain a quantity of cerebric acid or of lecithine. This has been variously called myeline (Virchow), protagon (Liebreich), and other names," so that, after all, lecithine and protagon are one and the same substance. These extracts will suffice to show with what extreme care any statement of Dr. Thudichum's must be received. In following the descriptions of other observers he appears to have confused their views. We can but consider the first part of the book as an ill-digested compilation from other authors, with a few facts noted by the author himself, expressed in grandiloquent language.

Of the second and larger part of the work under notice-the analytical guide-we can speak more favorably, though we differ from Dr. Thudichum in the opinion expressed in his preface, that this part of the treatise "is, perhaps, the most elementary that could be written for any practical purpose." On the other hand, we believe it to be unnecessarily complicated, and too much devoted to the description of obscure, and, we may add, doubtful, substances discovered, or supposed to have been discovered, by the author himself. Six pages only are devoted to a very imperfect examination of blood, whilst two are devoted to the extremely hypothetical substance which Dr. Thudichum dignifies by the term kryptophanic acid.

We fear that Dr. Thudichum's manual will do little to fill up the hiatus which our teachers of physiological and pathological chemistry lament, and that an English text-book on the subject is still a necessity.

\title{
XI.-Histories of Medicine.
}

THE works whose titles are given below, though differing much from each other both in plan and execution, and published

1. Histoire des Sciences Médicales, comprenant l'Anatomie, la Physiologie, la Médecine, la Chirurgie, et les Doctrines de Pathologie Générale. Par CH. Daremberg, Professeur chargé du Cours d'Histoire de la Médecine au Collége de France, Membre de l'Académie Impériale de Médecine, Bibliothécaire de la Bibliothèque Mazarine, \&c. Paris, 1870. 8vo, 2 vols., pp. xxviii and 1303.

History of Medical Sciences, comprising Anatomy, Physiology, Medicine, Surgery, and the Doctrines of General Pathology. Вy Сн. Darembera, Professor charged with the Course [of lectures] on the History of Medicine at the College of France, Member of the Imperial Academy of Medicine, Librarian of the Mazarine Library, \&c. Paris, 1870. 8vo, 2 vols., pp. xxviii and 1303.

2. Faculté de Médecine de Paris. Cours sur l'Histoire de la Médecine et de la Chirurgie. Par le Professeur CH. Daremberg. Leçon d'Ouverture, le 11 Novembre, 1871. Démonstration Historique de la Supériorité des Méthodes 
under different circumstances, have yet so much in common that they may very well be noticed together. Each work is the substance of a course of lectures on the history of medicine, delivered before an academical audience; and this fact might well suggest a useful hint to the medical schools in this country, in all of which (so far as we know) the history of our profession is completely ignored, although it surely might claim to be considered as a branch of knowledge, which (in the well-known words of Celsus), "quamvis non faciat medicum, aptiorem tamen medicinæ reddit," (lib. i, Proem.) Dr. Dunglison's little work has been published since his death under the editorial superintendence of his son, who tells us in the preface that it is " an embodiment of the course of lectures delivered by his father at the University of Virginia many years since." It was "the desire of Thomas Jefferson, at that time Rector of the University, and of those associated with that illustrious personage in its government, that the student should learn something of the earlier progress of the science and the art, while he was at the same time pursuing a course of instruction in the usual technical details of a collegiate medical education." Accordingly Dr. Dunglison (who was, we believe, one of the five professors from England who, with two Americans, formed the whole of the educational staff of the University when it was opened in April, 1825) "was expected to teach to the best of his ability, and with due diligence," not only anatomy, surgery, materia medica, and pharmacy, but also "the history of the progress and theories of medicine." It will thus be seen that "the arduous duties devolved upon him in that institution covered a much more comprehensive field than would be possible or practicable at the present day;" and that "the labour now usually allotted to almost an entire faculty of professors was there assigned to him alone." Under these circumstances it will readily be understood that we intend to impute no blame whatever to the author when we say that his work could not be otherwise than a compilation, and that he had no time for original research. As it was written probably about five and forty years ago, it would

d'Observation et Expérimentale sur les Méthodes à priori. Extrait de l'Union Médicale (3e série), Novembre, 1871. 8vo, pp. 16.

Faculty of Medicine of Paris. Course [of lectures] on the History of Medicine and Surgery. By Professor CH. DaREMBERG. Opening Lecture, Nov. 11, 1871. Historical Demonstration of the Superiority of the Methods based on Observation and Experiment over $\grave{a}$ priori Methods. Extracted from the "Union Médicale' (3rd series), Nov., 1871. 8vo, pp. 16.

3. History of Medicine from the Earliest Ages to the Commencement of the Nineteenth Century. By RoBLEY Dunglison, M.D., LL.D., late Professor of the Institutes of Medicine and Medical Jurisprudence in the Jefferson Medical College of Philadelphia, \&c., \&c. Arranged and Edited by RICHARD J. DunGLIson, M.D. Philadelphia, 1872. 8vo, pp. xii and 287. 
have been better to have published it nearer the time of its composition, when it, no,doubt, fairly represented the knowledge of medical history possessed by his contemporaries. It is now published because "it is believed that it will supply the want, long felt by the profession, of a condensed history [in English] of the progress of medicine, presenting all the main facts in systematic order, avoiding, as much as possible, prolixity or unnecessary discussion of the merits of men and theories, and not laying any claim whatever to the title of an exhaustive treatise." To a certain extent it will do this, and accordingly we recommend it to our readers as probably the most useful manual they are likely to meet with. At the same time, we must add that in our opinion the editor has scarcely done justice to his father's memory in printing a work, not prepared (perhaps not even intended) for publication, without doing more to remedy some of the omissions, and modify some of the statements, which were perfectly excusable forty years ago, but which the author (if we may judge by the care bestowed on successive editions of his 'Merlical Lexicon') would certainly not have allowed to continue uncorrected in the present day. If the work should reach a second edition (which may very possibly be the case), more care should be bestowed on the printing of the proper names and the titles of the works mentioned; and especially a series of references should be given to the authorities for the statements in the text. In this latter respect the work appears to disadvantage when compared with Bostock's "History of Medicine," (published in the "Cyclopædia of Practical Medicine,' and not often met with in a separate form), which is composed partly on the same plan, and is not the result of original research, but which from the numerous references at the foot of the pages gives the reader the means of continuing his investigations on any subject mentioned in the text on which he needs additional information. The chapter on Hippocrates requires to be corrected, both as the facts of his life, ${ }^{1}$ and the list of writings ascribed to him, by the result of the inquiries

1 One of the errors respecting the events of the life of Hippocrates, which has been corrected in print at least five times within the last five-and-twenty years, but which reappears in Dunglison's 'History,' (p. 108), we will notice again, and recommend the editor to correct in the next edition. In January, 1849, it was stated in this Review (vol. iii, p. 210), that the mistake made originally by Sprengel in his 'History,' who said that there was no chronological difficulty in the way of accepting the story about;Hippocrates and Perdiccas, king of Macedonia, had been repeated and perpetuated by Jourdan his French translator, by Rosenbaum his then recent editor, and by M. Littré, the editor of 'Hippocrates ;' but that it had been noticed and corrected by Dr. Greenhill, in Smith's 'Dict. of Biogr.,' (art. “'Hippocrates,”) and in Henschel's 'Janus' (vol. iii, p. 357). Since. that time the correction has been accepted and repeated by M. Littré, ('Hippocr.,' t. vii, p. xlix) and by Dr. Daremberg ('Hippocr.', p. xxix), and it is time that Sprengel's mistake should disappear from American books also. 
of Littré, Daremberg and Ermerins. The chapter on the "Medicine of the Hindoos" may be greatly improved by consulting Dr. Wise's 'History,' and also the work of Susruta, which has been published since this book was written. In fact we think that the whole work should be carefully revised, as, besides the numerous typographical errata, ${ }^{1}$ there are several statements and sentences in it, each of which we have not time to examine now, but which, taken altogether, prevent our considering it as perfectly trustworthy.

In turning to Dr. Daremberg's works, the first thing we notice is that when he delivers his opening lecture in November, 1871, he is a Professor at the Faculty of Medicine, whereas, in the titlepage of the two volumes published in 1870, he appears only as a Professor charged with a course of lectures at the College of France. The difference is important, and bears upon a point of the history of medical education in France, of which the professor gives us an interesting sketch, and which we will briefly lay before our readers. It appears that towards the end of the last century, when the École de Sante (afterwards called the "Faculté de Médecine") was reorganized by the Committee of Public Instruction, a professorship was appointed for "legal medicine" and for the " history of medicine" (1794). Shortly afterwards (1795) the librarian of the school (Peter Sue) was appointed to lecture on "Medical Bib. liography," and Thouret, the Director, on the "Doctrine of Hippocrates." In 1799 Thouret applied for the foundation of a professorship of the "Philosophy of Medicine"; but the application was not granted, and the existing professorships were in process of time amalgamated, and, finally, suppressed in 1822. In $1837 \mathrm{M}$. Dezeimeris, the librarian of the Faculty, applied for the re-establishment of the professorship of medical history, but without success; and the same result attended some other attempts made in the same direction in ' 45 and ' 59. But though it was not possible to procure the re-establishment of the professorship at the Faculty of Medicine, Dr. Daremberg was, in 1864, commissioned to deliver lectures on Medical History at the College of France; and it is the result of these lectures, delivered in the years 1864-67, that he has now given to the world in the form and with the title of a 'History of the Medical Sciences.' Thus, then, a sort of readership was

\footnotetext{
1 Some of these mistakes, however, would seem to be due to the author, and not the printer: as, for instance, "Alexander of Damas," p. 172 (for Damascus), which is evidently taken from the French translation of Sprengel's 'History," (tome ii, p. 100); “De Methodo Medendi ad Glauconem" (p. 174), where the last two words should be omitted, and where he seems to have mistaken Sprengel's reference (tome ii, p. 103) ; - but what is to be said for the strange word "scientist," used for a scientific man (p. 34)?
} 
established, which promoted the study of medical history by employing a competent person to give his time and attention to the subject; but, the matter has at last been finally settled on a more permanent and satisfactory basis. In July, 1869, it was announced in the French medical journals that a M. de Champotran, a former "mâitre des requêtes," had left a considerable sum to the Faculty of Medicine of Paris for the purpose of founding a professorship of medical history. He had been induced to take this step by the advice of his surgeon, M. Cusco, whom in his will he recommended to the Faculty as a person perfectly capable of fulfilling the duties of the office. M. Cusco, however, declined the place, and Dr. Daremberg (probablv the fittest person that could have been found) was appointed the new professor. This was shortly before the breaking out of the late war, which, of course, put a stop to medical lectures, as well as to many other things of more importance. During the siege of Paris by the Germans, Dr. Daremberg remained in the city, kept partly by his employment at the Mazarine Library, of which he is one of the librarians, and partly by his duty to his sick and wounded fellowcitizens, in which he was well seconded by his young son, who, we believe, was only a medical student at the time. Our readers will not be surprised to hear that the events of that terrible siege (the bodily fatigue, the scanty and unwholesome food, and the mental anxiety), have left their traces behind, from the effects of which it is probable that the Professor will never entirely recover. ${ }^{1}$

And now, having given an account of the establishment of the professorship, which is itself (as Dr. Daremberg says) "une question historique," we will turn to the work itself; and in this it seems to us that almost everything is good except the name, which is badly chosen. Perhaps we may explain our meaning at once when we say that if it had been called a 'Course of Lectures on Medical History,' we should have found it a delightful book, with which no one would have had a right to find fault; but that if it is to be called a ' History of the Medical Sciences,' there seem to us to be grave faults in the plan of the work (or rather in the disproportion of its several parts), and perhaps now and then in the execution also. In a course of lectures on any subject the Professor (unless, indeed, he intends to give a complete and systematic treatise merely cut up into lectures instead of chapters) may enjoy a certain amount of latitude in the choice of what he mentions and what he omits to notice. But surely, in a history, the writer has no such

I In his opening lecture, he touchingly alludes to " ma voix un peu haletante," " mon visage fatigué," "la souffrance qui me trouble" 
liberty; he should exclude all extraneous matter (or at least throw it into the form of an appendix or notes), however convenient or tempting it may be to insert it; and he should not only mention whatever deserves to be mentioned, but he should also preserve a due proportion between the several parts, in accordance with their relative importance. And this is what Dr. Daremberg has not done, and therefore we repeat that if it is to be considered as a work of art, a real history, as distinguished from a series of historical sketches, it appears to us to be seriously defective. We will illustrate our position by a few instances:-The most flagrant cases of disproportion are those of Paracelsus and Van Helmont, to the former of whom the Professor allots no less than one hundred and nine pages, and to the latter seventy-six, thus occupying one seventh part of the whole work with these two personages. As they have received more than their due amount of commendation from some modern writers, perhaps it was necessary to represent them in their true colours, and this Dr. Daremberg has probably done more completely than any of his predecessors. The two chapters are full of interesting and (in a certain sense) original matter ; but we would suggest to the Professor that, after the delivery of these lectures, the proper thing to do with them would have been to publish them as a separate brochure, and not to have marred the symmetry of his work by inserting them at full length therein. ${ }^{1}$

The same objection (though not to the same extent) may be brought against the account of Sylvius de la Boe, to whom are assigned thirty pages, and that of the iatro-mathematical (or iatro-mechanical) school, which occupies 200 ; but then it must be borne in mind that to this school belonged an unusual number of eminent men, e.g. Borelli, Bellini, Pitcairne, Boerhaave, Hoffmann, \&c.

This want of symmetry, which is so great that it indicates a certain amount of want of judgment also, and which appears to us to be the chief blemish in the book, can easily be removed in a second edition; and, perhaps, if it is still to be called a history, those passages which belong simply to a course of lectures may be omitted with some economy of space, and without lessening the interest or value of the work.

The general character of the book is such as might be expected by any one who has read Dr. Daremberg's former writings, in which we find extensive, accurate, genuine learning

1 To make the matter still more striking (if necessary) we may mention the space allotted respectively to some of the most celebrated physicians of ancient and modern times :- Hippocrates, 56 pages; Galen, 30 ; Harvey, 44; Sydenham, 28 ; Boerhaave, 16; Haller, 10 ; Bichat, 11 ; Cullen, 18. 
(brought forward whenever it is required, but never without necessity, or for the mere purpose of display), enlivened by a lively (but not flippant or jocose) style, and by just and healthy sentiments. All his books are thoroughly trustworthy, and though few writings are less in need of correction than his, it adds to our confidence in his conscientious accuracy when we find him not ashamed to give a list of "Errata and Addenda." Of particular portions of the work it would be out of place here to speak at length, but we may say that Englishmen will be pleased to observe that so competent a judge does full justice to the merits of our countrymen, Harvey and Sydenham. The history of the circulation of the blood especially is a subject in which the Professor's intimate acquaintance with the opinions of the older anatomists and physiologists enables him to estimate at their true value the attempts still occasionally made to deprive Harvey of the glory of his discovery.

He gives a "Chronological Table of the Alexandrian Physicians, with a Summary of their Works," in some respects better and more complete than any previously existing, which with the accompanying "Notes Justificatives" he very properly calls an "Appendix" to Chapter VII. Another very valuable "Appendix" contains a "Study on the Different Classifications of the Periods of MedicalHistory," with (incidentally) a critical judgment on the writers. In making this examination, the Professor has of course expressed his opinion of the different works passed in review with considerable freedom, but he does not seem to us (so far as we have observed) to have gone beyond the fair limits of criticism, or to have forgotten the excellent sentence of Mead (Preface to 'Medical Precepts and Cautions'), with which he closes his own preface, and which it would be a good thing if other medical writers (including reviewers) would more constantly bear in mind:- "The very nature of my design compelled me to take notice of the errors of other physicians; but I have been very careful throughout the work to do it with the same equity with which I would desire to have my own faults corrected." The Professor easily discovers the defects in the classifications of his predecessors, but perhaps he has not been so successful in devising one which is quite free from objections, when proposing the eight epochs (p. 25, \&c.) into which he has divided his subject, and which are not in each case very distinctly marked out. The first he calls " theurgic or empiric" (perhaps not very well chosen names), by which he appears to mean the primitive medicine in the hands of priests, \&c., and such as is shown in the hymns of the Hindoos in the " Rig Véda.' The second and third he joins together (p. 79), and they carry us to Hippocrates (inclusive); the fourth compre- 
hends the Álexandrian school, with Herophilus, Erasistratus, \&c.; the fifth includes Galen; the sixth extends to the fifteenth century; the seventh ends with the publication of the first edition of Harvey's work, 'De Motu Cordis et Sanguinis,' in 1628 ; and the eighth and last continues at the present time. This bare enumeration of the Professor's eight epochs, though without giving the reasons for his classification, may be enough to let our readers see that the classificatiou may (like most similar arrangements) be considered as more or less arbitrary, and that the number of the classes might be either increased or diminished with equal plausibility.

In taking leave of the Professor, we beg to offer him our best thanks for his most valuable and interesting book, our sincere congratulations on the well merited professorship, and our hearty good wishes that he may soon be so far restored to health and strength as to be fit to resume the duties of his office, which probably no one in Europe would be able to perform so efficiently as himself.

\section{XII.-Fayrer's Poisonous Serpents of India. ${ }^{1}$}

THE subject of snake-poisoning has recently attracted very considerable attention. Much has been drawn to it by the observations made by Professor Halford, of the Melbourne University, on the effects of the injection of liquor ammoniæ in poisoning by the Australian snakes, and on the microscopic changes which he believed he observed in the blood of animals killed by their bite. The costly and magnificent work before us, although it in no respect confirms Professor Halford's observations, at least, in as far as they were expected to apply to the Indian snakes, is a very valuable fruit of the attention which has been called to the subject by the writings of the Melbourne Professor. In it Professor Fayrer has given us, first, a good zoological account of the Indian Thanatophidia, in the descriptions and definitions following Günther and other authors of repute, but supplementing their accounts with many original facts and observations of great interest; secondly, some valuable statistical information proving the great amount of mortality from snake-bite in the State of Bengal ; thirdly, a treatise on the treatment of snake-bite based on the records of many

1 The Thanatophidia of India, being a Description of the Venomous Snakes of the Indian Peninsula, with an Account of the Influence of their Poison on Life; and a Series of Experiments. By J. FAYRER, M.D., C.SI., F.R.S.E. Fol., p. 156. London, 1872. 